\title{
Evaluation and Analysis on Tax Synergistic Effects in Merger and Acquisition of Chinese Listed Companies
}

\author{
Yuefang Guo ${ }^{1,2}$ \\ ${ }^{1}$ School of Management, Huazhong University of Science and Technology, Wuhan, Hubei Province, \\ China, 430074 \\ ${ }^{2}$ Business College, Xinyang Normal University, Xinyang, Henan Province, China, 464000
}

\begin{abstract}
Keywords: Merger And Acquisition Of Companies; Tax Synergistic Effects; Parametric And
\end{abstract} Nonparametric Test.

\begin{abstract}
In this paper, factors include preferential tax, target enterprise's loss, debt tax shield and depreciation shield are all taken into account. Principal component analysis method is used to construct comprehensive scoring functions and evaluate tax synergistic effects of listed companies after mergers and acquisitions. Parametric and nonparametric tests are employed to analyze the influences of enterprise's asset scale, target enterprise's loss, correlation of M\&A, mode of payment and related transaction on tax synergistic effects.
\end{abstract}

\section{Introduction}

Targets of mergers and acquisitions depend on motivations of M\&A. The impacts of tax on mergers and acquisitions mean that some companies carry out M\&A strategy in order to obtain tax benefits. Researchers do not reach consensus on the impacts of tax on M\&A target selection, especially on whether tax benefit is an important factor which affects the choice of M\&A target. Alan J. Auerbach (1983) argues that there is not enough convincing evidence on the decisive role of tax in the choice of M\&A target. [1] Alan J. Auerbach and M. Poterba (1987) believe that perhaps, tax does not have a decisive role in acquisition targets, but it could have significant impacts on other aspects, such as the timing of M\&A. Gilson and Ronald J. (1988) consider that the theoretical basis of the decisive role of tax in M\&A targets selection is relatively weak.

Supportive views come from researchers such as Charles Steindel (1986), who believes that tax policy changes in America, 1986 led to the significantly increase of mergers and acquisitions. Maid and Myers (1985) find that two profitable companies can also choose M\&A to reduce their future tax obligations; tax saving shows a negative correlation with companies' cash flows before mergers. [2] Therefore, these companies are more likely to become acquisition targets. Carla Hayn (1989) shows that companies with various tax properties are easily to become the target of mergers and acquisitions; favorable tax attributes brought by target enterprises even become the key factor in M\&A decisions.

However, as Mark L. Sirower (1997) points out that, there are traps in M\&A synergistic effects. Do mergers and acquisitions really bring tax synergistic effects? Is there a trap in tax synergy, too? On the basis of a comprehensive evaluation on tax preference, target enterprise's loss, debt tax shield and depreciation shield, this paper analyzes the tax synergistic effects of listed companies after M\&A through classification and comparative analyses. Research design, empirical analyses and conclusions are provided afterwards.

\section{Research Design}

Sample selection and data sources. This paper intends to investigate data of list companies after M\&A for continuous four years from 2009 to 2012. In this study, data of acquiring enterprise comes from asset transfer database CCER; financial data comes from RESSET database; target enterprise information comes from merger announcements published in Sina Financial Network. After excluding financial enterprises, non-profitable companies, as well as non-financial firms with incomplete information or extreme variables, 277 acquiring enterprise are collected as samples. At 
the same time, according to the industry distribution of samples, we randomly selects 277 listed companies in CCER asset transfer database from 2009-2012 as matched samples.

Variable definition and research methods. Selection of original variables. Tax saving. In this paper, the actual income tax rate is obtained from the formula (income tax + deferred income tax assets - deferred income tax liabilities)/ total profits. Since the actual income tax rate and tax effect are negatively related, the difference between company's statutory tax rate and income tax rate is obtained as the index value for tax saving; the value and tax synergistic effects are positive related. [3][4]

Tax synergistic effect T. Synergistic effect of taxation is enterprises' tax savings realized through mergers and acquisitions. The difference of tax effect before and after the merger is equal to the number. The synergistic effect of the ith company in the kth year $\mathrm{T}^{\mathrm{k}}{ }_{\mathrm{i}}=\mathrm{F}^{\mathrm{k}}{ }_{\mathrm{i}}-\mathrm{F}^{0}{ }_{\mathrm{i}}$. The next empirical analysis choose to use the annual average tax synergy as the representative value of tax synergistic effects after M\&A, namely $\mathrm{T}_{\mathrm{i}}=\left(\mathrm{T}^{1}{ }_{\mathrm{i}}+\mathrm{T}^{2}{ }_{\mathrm{i}}+\mathrm{T}^{3}{ }_{\mathrm{i}}+\mathrm{T}^{4}{ }_{\mathrm{i}}\right) / 4$

Comparative analysis of tax synergistic effects. In order to further examine the tax synergistic effects of listed companies after mergers and acquisitions, 5 classification methods in Table 1 are used to analyze the impacts of each factors on tax synergistic effects through $\mathrm{KW}$ test and multilevel one-way analysis of variance.

Research methods. Tax effect F. According to the principal component analysis method, the comprehensive score function of tax effect is $\mathrm{F}^{\mathrm{k}}{ }_{\mathrm{i}}=\sum \alpha^{\mathrm{k}}{ }_{\mathrm{ij}} \mathrm{X}^{\mathrm{k}}{ }_{\mathrm{ij}}(\mathrm{k}=0,1,2,3,4 ; \mathrm{i}=0,1 \ldots 324 ; \mathrm{j}=1,2,3)$. Among them, $\mathrm{F}^{\mathrm{k}}{ }_{\mathrm{i}}$ is the comprehensive score of tax effect for the ith company in the kth year after mergers and acquisitions ( $\mathrm{k}=0$ means the year before $M \& A) . \alpha^{\mathrm{k}}$ ij is the variance contribution rate of $\mathrm{jth}$ factor in the kth year; $\mathrm{X}_{\mathrm{i}}^{\mathrm{k}}$ is the score of the $\mathrm{jth}$ factor for the ith company in the kth year.

Tax synergistic effect T. Synergistic effect of taxation is enterprises' tax savings realized through mergers and acquisitions. The difference of tax effect before and after the merger is equal to the number. The synergistic effect of the ith company in the kth year $\mathrm{T}^{\mathrm{k}}{ }_{\mathrm{i}}=\mathrm{F}^{\mathrm{k}}{ }_{\mathrm{i}}-\mathrm{F}^{0}{ }_{\mathrm{i}}$. The next empirical analysis choose to use the annual average tax synergy as the representative value of tax synergistic effects after M\&A, namely $\mathrm{T}_{\mathrm{i}}=\left(\mathrm{T}^{1}{ }_{\mathrm{i}}+\mathrm{T}^{2}{ }_{\mathrm{i}}+\mathrm{T}^{3}{ }_{\mathrm{i}}+\mathrm{T}^{4}{ }_{\mathrm{i}}\right) / 4$

Comparative analysis of tax synergistic effects. In order to further examine the tax synergistic effects of listed companies after mergers and acquisitions, 5 classification methods in Table 1 are used to analyze the impacts of each factors on tax synergistic effects through KW test and multilevel one-way analysis of variance.

Table 1. Tax synergy effect factors

\begin{tabular}{l|l|l}
\hline sign & name & definition \\
\hline GM & $\begin{array}{l}\text { asset size of acquiring } \\
\text { enterprise }\end{array}$ & $\begin{array}{l}\text { divided into 6 categories in accordance with asset sizes of } \\
\text { acquiring enterprises (unit: 100 million yuan) }\end{array}$ \\
\hline KS & Target enterprise's loss & 1 represent loss, 0 represent profit \\
\hline ZF & Payment method & 1 represent cash payment, 0 represent non cash payment \\
\hline BX & correlation of M\&A & $\begin{array}{l}1 \text { represent related acquisition, including horizontal and } \\
\text { vertical acquisition; 0 represent non-related acquisition, } \\
\text { namely the conglomerate M\&A }\end{array}$ \\
\hline GL & related transaction & $\begin{array}{l}1 \text { represent related transaction, 0 represent non-related } \\
\text { transaction }\end{array}$ \\
\hline
\end{tabular}

*Note: the following classification method is taken: 1) $0<\mathrm{GM} \leqslant 1$ billion yuan; 2) 1 billion yuan $<\mathrm{GM} \leqslant 5$ billion yuan; 3) 5 billion yuan $<\mathrm{GM} \leqslant 10$ billion yuan; 4) 10 billion yuan $<\mathrm{GM} \leqslant 20$ billion yuan; 5) 20 billion yuan $<\mathrm{GM} \leqslant 50$ billion yuan; 6) 50 billion yuan $<\mathrm{GM} \leqslant 700$ billion yuan.

\section{Empirical Analyses}

Descriptive statistical analyses. The actual income tax rate and tax rate saving. The actual income tax rate index examines the losses of target companies and the effects of tax preference. [7] 
During the year before merger and acquisition, as well as the first to the fourth year after M\&A, the mean of companies' actual income tax rate is generally lower than the mean of actual income tax rate of their matched samples over the same period. After M\&A, the actual income tax rate increases year by year. The average tax rate declines from the second years of acquisition; in the fourth year, the sample tax rate goes down to the level below average level. The average tax rate of the sample is generally higher than matched samples, but it shows a downward trend, which indicates that mergers and acquisitions reduce tax rate.

Debt tax shield effect. Debt tax shield effects of M\&A samples are prominent. Asset liability ratio of M\&A samples is about 4\% lower than matched samples for the same period. But since the first year of acquisition, the asset liability ratio begins to rise, and becomes equal to or exceed the matched sample in the fourth year. During 2010-2015, asset liability ratio of matched samples shows a slow downward trend, while the asset liability ratio of merger samples shows a slowly rising trend, which represent that mergers and acquisitions improve companies' debt capacities, and significantly enhance debt tax shield effects.

Depreciation shield effect. The mean ratio of income to depreciation and amortization of M\&A samples before the merger is lower than the mean ratio of matched samples; after M\&A the ratio gradually catches up with and surpasses the matched samples, and shows upward trend. It shows that mergers and acquisitions increase the proportion of depreciation and amortization to business income for acquiring companies; the tax shield effects are strengthened after mergers and acquisitions.

Empirical analyses. Tax synergistic effects in merger and acquisition. According to above definition, the tax synergistic effects of the ith company in the kth year of merger and acquisition is $\mathrm{T}_{\mathrm{i}}^{\mathrm{k}}=\mathrm{F}_{\mathrm{i}}^{\mathrm{k}}-\mathrm{F}_{\mathrm{i}}^{0}$. The average tax synergistic effect achieved by the ith acquiring enterprise is $\mathrm{Ti}=(\mathrm{T} 1 \mathrm{i}+$ $\mathrm{T} 2 \mathrm{i}+\mathrm{T} 3 \mathrm{i}+\mathrm{T} 4 \mathrm{i}$ ) /4. 40\% acquiring enterprises obtain positive tax synergistic effects; $60 \%$ acquiring enterprises achieve negative tax synergistic effects. In general, the number of samples with negative tax synergistic effects is greater than the number of samples with positive tax synergistic effects.

Classification and comparison of influencing factors of tax synergistic effects in M\&A

The empirical results are shown in table 2.

The scale of enterprise assets. In Table 1, the assets of acquiring enterprises are divided into 6 categories. According to non parametric $\mathrm{KW}$ test results and multilevel single factor variance analysis, asset size has significant influences on tax synergistic effects in the first and third year of M\&A. Thus, asset size is a main factor of tax synergistic effects.

Target enterprise's loss. The results of parametric and non parametric tests show that, the loss of target enterprise has significant effects on tax synergy of the second and third year. The mean comparison finds that, synergistic effects of unprofitable target enterprises are lower than the mean of tax synergistic effects of profitable target enterprise; this gap is enlarged in the second year of M\&A. It may because that the financial risks of unprofitable firms increase debt tax shield effects, then decrease depreciation shield effects and offset the tax savings of acquiring enterprises, resulting in "traps" in tax synergistic effect.[8]

Correlation of tax synergy and M\&A. According to the results of empirical test, correlation effect in M\&A has a significant impact on tax synergy in the third and fourth years on the level of $10 \%$. Non-related mergers and acquisitions are not conducive to tax synergistic effects. The reason may be related to the difficulties of target companies' integration into unrelated industry.

Related transactions. The empirical results show that, related transactions have significant influences on the average tax synergy effect in the first and fourth year of merger and acquisition on the level of $1 \%$. In the first year of M\&A, tax revenue synergistic effects of non-related transactions are greater than related transactions. But in the fourth year, tax revenue synergistic effects of non related transactions are smaller than related transactions. This phenomenon indicates that non-related transactions are conducive for enterprises to obtain synergistic effects in the first year of acquisition, but the tax saving effects of related transactions increase significantly after four years of M\&A. The potential of related transactions on tax synergy is greater than non related transactions after merger and acquisition conformity. 
Statistical analysis shows that, the payment method has no effect on tax synergy effects. In 277 samples, most acquiring firms choose cash payment. Modes of mergers and acquisitions only affect the type of pre-merger transaction (taxable or tax-free) and the income tax burden of shareholders in target companies; they do not have significant influences on tax effects of acquiring companies after M\&A.

Table 2. Classification test results of tax synergistic effects in M\&A.

\begin{tabular}{|c|c|c|c|c|}
\hline $\begin{array}{l}\text { explaining varia } \\
\text { ble }\end{array}$ & $\begin{array}{l}\text { explained vari } \\
\text { able }\end{array}$ & Test method & Test statistics & P value \\
\hline \multirow{6}{*}{$\begin{array}{l}\text { asset size of } \\
\text { acquiring } \\
\text { enterprise }\end{array}$} & \multirow[t]{2}{*}{$\mathrm{T} 1$} & KW test & $\begin{array}{l}\text { chi-square } \\
=107.129\end{array}$ & 0.00 \\
\hline & & $\begin{array}{l}\text { one-way analysis of va } \\
\text { riance }\end{array}$ & $F=27.734$ & 0.00 \\
\hline & \multirow[t]{2}{*}{$\mathrm{T}_{3}$} & KW test & $\begin{array}{l}\text { chi-square } \\
=17.238\end{array}$ & 0.003 \\
\hline & & $\begin{array}{l}\text { one-way analysis of va } \\
\text { riance }\end{array}$ & $F=2.559$ & 0.028 \\
\hline & \multirow[t]{2}{*}{ MT } & KW test & $\begin{array}{l}\text { chi-square } \\
=37.213\end{array}$ & 0.00 \\
\hline & & $\begin{array}{l}\text { one-way analysis of va } \\
\text { riance }\end{array}$ & $F=5.153$ & 0.00 \\
\hline \multirow[t]{3}{*}{$\begin{array}{l}\text { Target } \\
\text { company’s }\end{array}$} & \multirow[t]{2}{*}{$\mathrm{T}_{2}$} & KW test & $\begin{array}{l}\text { chi-square } \\
=3.078\end{array}$ & 0.004 \\
\hline & & $\begin{array}{l}\text { one-way analysis of va } \\
\text { riance }\end{array}$ & $F=10.894$ & 0.001 \\
\hline & $\mathrm{T}_{3}$ & $\begin{array}{l}\text { one-way analysis of va } \\
\text { riance }\end{array}$ & $F=3.3889$ & 0.05 \\
\hline \multirow[t]{2}{*}{$\begin{array}{l}\text { correlation of } \\
\text { M\&A }\end{array}$} & $\mathrm{T}_{3}$ & KW test & $\begin{array}{l}\text { chi-square } \\
=3.324\end{array}$ & 0.067 \\
\hline & $\mathrm{T}_{4}$ & $\begin{array}{l}\text { one-way analysis of va } \\
\text { riance }\end{array}$ & $F=3.105$ & 0.079 \\
\hline \multirow{3}{*}{$\begin{array}{l}\text { Related } \\
\text { transaction }\end{array}$} & \multirow[t]{2}{*}{$\mathrm{T}_{1}$} & KW test & $\begin{array}{l}\text { chi-square } \\
=153.5\end{array}$ & 0.00 \\
\hline & & $\begin{array}{l}\text { one-way analysis of va } \\
\text { riance }\end{array}$ & $\mathrm{F}=12.224$ & 0.001 \\
\hline & $\mathrm{T}_{4}$ & KW test & $\begin{array}{l}\text { chi-square } \\
=2.872\end{array}$ & 0.093 \\
\hline
\end{tabular}

\section{Conclusions}

This paper uses principal component analysis method to evaluate the tax synergistic effects of listed companies in the first fourth years after mergers and acquisitions, and test the tax synergistic effects through parametric and non parametric ways from the perspectives of enterprise asset, loss of target company, correlation of merger and acquisition, related transaction and payment mode. The main conclusions are as follows:

For acquiring enterprises, mergers and acquisitions improve actual income tax rates, asset liability ratios and the ratios of depreciation and amortization to income. Related mergers and acquisitions of listed companies are more than non related M\&A; most M\&A belongs to related party mergers and acquisitions; listed companies prefer cash payment.

There are traps of tax synergy effect in M\&A. Target enterprises with losses often get lower tax synergy effects in M\&A, while profitable target enterprises get high tax synergy effects in M\&A. 
Assets sizes of acquiring enterprises have a significant impact on tax synergistic effects. The greater of enterprise's asset size, the greater tax synergistic effects will be.

Related M\&A and non related M\&A are not conducive to positive tax synergy effects. Payment modes do not have significant effects on tax synergy effects after M\&A.

\section{References}

[1]A. J. Auerbach, D. Reishus, The Effects of Taxation on the Merger Decision. NBER Working Paper. W2192, 1990.

[2] S. Maid, S. Myers, Valuing the government's tax claim on risky corporate assets. NBER Working Paper. No.1553, 1985.

[3] B. Ayers, C. Lefanowicz, J. Robinson, Capital gains taxes and acquisition activity: evidence of the lock-in effect, J. Contemporary Accounting Research. 24 (2007).

[4]Ayers B., Lefanowicz C., Robinson J., The effect of shareholder-level capital gains taxes on acquisition structure, J. The Accounting Review. 79 (2004).

[5] A. J. Auerbach, D. Reishus, Taxes and the Merger Decision. NBER Workingpaper. 1855\#, 1986.

[6] D. Dhaliwal, M. Erickson, S. Heitzman, The effect of seller taxes on acquisition prices: Evidence from purchases of taxable and tax-exempt hospitals, J. Journal of the American Taxation Association. 26 (2004).

[7] E. Eckbo, Horizontal mergers, collusion, stockholder wealth, J. Journal of Financial Economics. 11 (1983).

[8] M. Erickson, S. Wang, The effect of transaction structure on price: evidence from subsidiary sales, J. Journal of Accounting and Economics. 3 (2000). 